Egyptian Journal of Aquatic Biology \& Fisheries

Zoology Department, Faculty of Science,

Ain Shams University, Cairo, Egypt.

ISSN $1110-6131$

Vol. 25(4): 379 - 399 (2021)

www.ejabf.journals.ekb.eg

\title{
Chemical Composition and Nutritional Value of Dried Fish in Bangladesh
}

\author{
Md. Golam Rasul ${ }^{1 *}$, Chunhong Yuan ${ }^{2}$ and A.K.M. Azad Shah ${ }^{1}$
}

${ }^{1}$ Department of Fisheries Technology, Faculty of Fisheries, Bangabandhu Sheikh Mujibur Rahman Agricultural University, Gazipur - 1706, Bangladesh

${ }^{2}$ Department of Food Production and Environmental Management, Faculty of Agriculture, Iwate University, 3-18-8 Ueda, Morioka, Japan

*Corresponding Author: rasul@bsmrau.edu.bd

\section{ARTICLE INFO}

Article History:

Received: Oct. 10, 2020

Accepted: June 19, 2021

Online: July 15, 2021

Keywords:

Dried fish,

Protein,

Lipid,

Mineral,

Health benefits

\section{ABSTRACT}

Nowadays, people are very conscious about health and nutritional issues and they concern about the nutritional value of the dried fish when they buy these foods for their household consumption. The review article mainly focused on the chemical composition of dried fishes of Bangladesh including protein and amino acid, fats and fatty acid profile, and minerals along with their health benefits. Dried fish is a specially processed fishery product along with high nutritional value and health benefits due to important nutritional components. The principal components of dried fish are high-quality protein and amino acids. It also contains lipids, polyunsaturated fatty acids, especially eicosapentaenoic acid (EPA) and docosahexaenoic acid (DHA); richer mainly in marine dried fish. Small dried fishes contain more mineral contents such, as calcium, iron, potassium, sodium, phosphorus, zinc, etc. compared to the larger ones. Therefore, the consumption of dried seafood has beneficial effects on human health. It helps in forming body tissues, antibodies, and enzymes, repairing wornout tissues, with the decreased risk of coronary heart and cardiovascular diseases. In addition, it cures inflammatory diseases such as arthritis and prevents cancer, reduces lower insulin resistance, triglyceride, and obesity, and improves hyperglycemia, etc. While undernutrition is still negatively affecting the health and well-being of many people. Based on proximate composition, amino acids, fatty acids profile, and minerals, it can be concluded that dried fish can be a good source of health beneficial nutrients for humans.

\section{INTRODUCTION}

Fish is one of the most perishable food items and several preservation methods are implemented worldwide for preserving fish. Like other tropical countries, in Bangladesh fish drying is a prime and an inexpensive preservation method (Balachandran, 2001; Jain \& Pathare, 2007; Majumdar et al., 2018). Drying implies the removal of water from the fish body through evaporation with the effect of the sun and wind which gives characteristic color texture and flavor of the fish products (Nowsad, 2005). The consumer preference of the dried fish product is not only because of their traditionally desirable 
taste and flavor, but also their high content of (n-3) polyunsaturated fatty acids especially in fish lipids. These fatty acids seem to have various health benefits, such as decreasing the risk of stroke, reducing serum triacylglycerol levels, reducing blood pressure, and insulin resistance and modulating the glucose metabolism (Li, et al., 2003).

Bangladesh earns a significant amount of foreign currency by exporting dried fish and fishery products and has a good position in the export item of fish and fishery products. Exporting of dried fish has also increased at a huge rate since the beginning of the $21^{\text {st }}$ century. In 2001-02, about 517 MT dried fish was exported and the value was 832 million BDT. While, Bangladesh earned about 4259 million BDT as foreign currency by exporting about 3143.93 MT of dried fish and fishery products in 2017-2018 (DoF, 2018).

Human body requires a good protein source and other essential nutrients for the maintenance of a balanced health (Arannilewa et al., 2006). In Bangladesh, fish is one of the major sources of animal protein, specifically dried fishes that provide humans with important elements necessary for keeping sound health (Ravichandran et al., 2012). Dried fishery products contain valuable nutritional components for human beings and essential nutrients for balanced and healthy body (Koffi-Nevry et al., 2011; Sutharshiny \& Sivashanthini, 2011). Dried fishes are low cost dietary protein source and used most frequently as a substitute of fish at the scarcity of fresh fish (Khan \& Khan, 2001; Rahman et al., 2017). Some people do like to consume dried fish products of some freshwater and marine fish species rather than consuming fresh fish. Additionally, dried fish is the most accessible type of processed fish for consumers matching with all income levels. In Bengladish, because of the high demand of the dried products, a sizeable quantity of fish from freshwater and marine fish is sun dried. About $20 \%$ of the total marine catch from the coastal region of Bangladesh is sun dried and sold in the domestic market (Alam, 2010; Begum et al., 2012; Hasan et al., 2016).

In Bangladesh, more than 20 million people, particularly women and young children, suffer from chronic deficiencies of protein and micronutrients (Ahmed et al., 2012). The protein requirement for the rural people is $0.8 \mathrm{gm} / \mathrm{kg}$ of body weight. This requirement of protein and micronutrients can be covered by dried fish products. A good quality dried fish can provide 52-73\% of protein (Sultana et al., 2011), thus if one eats 100 grams of dried fish in a day, he would have the required protein for the body. The dried products processed from small fishes contain very light amount of cholesterol, and interestingly, they are rich in vitamins and minerals like-iron, calcium and phosphorous (Salaudeen, 2014). The dried fishes have the better nutrient profile and act as an alternative source of protein for people in Bangladesh. In this review article, the chemical composition of different freshwater and marine dried fishes are studied to assess their nutritional value along with their health benefits. 


\section{Chemical composition of dried fish}

The chemical composition analysis is the method of determining the values of the moisture, protein, lipid, ash, carbohydrate, vitamin and extractive present in the food samples expressed as the percentage value. Dried fish is an important source of crude protein, amino acids, water, lipids, fatty acids and ash or minerals. The proximate compositions (i.e. moisture, protein, lipid, ash) are important parameters of fishery product quality assessment, which influence the nutritive value, quality, functional properties and sensory properties of fishery product (Kar et al., 2020). The composition of a particular species often appears to vary from one habitat to another, and season to season, but changes in this composition are usually caused due to the variation in the amount and the quality of food eaten by fish and in the amount of their movement (Abdullahi 2001; Effiong \& Fakunle, 2011; Rasul et al., 2021). In fresh fish, the flesh generally contains up to $65-90 \%$ moisture, $10-22 \%$ protein, $1-20 \%$ fat and $0.5-5 \%$ minerals (Sankar et al., 2010; Radhika, 2018). Different processing methods cause a considerable change in this composition. In comparison of fresh fish, the drying process results in a significant decrease in moisture content and an increase in other nutritional components, such as protein, lipid, and ash percentages (Nowsad, 2005). In this context, it was noted that, the nutritional value of a kilogram of dried fish is the same as approximately five kilograms of fresh fish (Salaudeen, 2014).

\section{Moisture content in dried fish}

The moisture of all living systems contributes as much to the essential properties of life. Thus, it is an important body constituent of fish. While, the water content of fresh fish remains high, drying removes the water from the flesh and reduces the water activity, making the water inaccessible to microorganisms, extending the shelf life of dried products (Nowsad, 2005). In this essence, Sultana et al. (2011) found that, the moisture content ranges in some dried small indigenous species (SIS) like Mystus tengra, Amblypharyngodon mola, Pseudeutropius atherinoides, Corica soborna, Chanda baculis, Chanda ranga and Oxygaster bacaila of Bangladesh from 10.2\% to 13.9\%. Hoq (2004) reported that normally the sun-dried fishes contain an average of $10 \%$ to $20 \%$ moisture. This also makes the dried product edible for longer period and simultaneously increases other nutrients in the product that are beneficial for human health. The moisture percentage in some freshwater SIS ranged from 12.7\%-27.52\% in dried Mystus vitatus (Nurullah et al., 2006; Hasan et al., 2006; Sultana et al., 2011; Flowra et al., 2012; Rana et al., 2019). While the moisture was 12.9\%-29.25\% in dried Amblypharyngodon mola (Nurullah et al., 2006; Hasan et al., 2006; Sultana et al., 2011; Islam et al., 2013; Rana et al., 2019), and 25.13\%-31.35\% in Puntius sophore (Islam et al., 2013; Rana et al., 2019). In addition, it was $10.9 \%-26.26 \%$ in Pseudeutropius atherinoides (Nurullah et al., 2006; Sultana et al., 2011), and 12.0\%-28.2\% in Corica soborna (Hasan et al., 2006; Sultana et al., 2011; Flowra et al., 2012; Rana et al., 2019). Additionally, the rate 
of fish moisture was 26.24\%-27.32\% in Gudusia chapra (Nurullah et al., 2006; Rana et al., 2019), $21.8 \%$ in Chanda nama and $18.18 \%$ in Palaemon sp. (Flowra \& Tumpa, 2012). Moreover, $23.26 \%$ of moisture content was detected in Osteobrama cotio (Nurullah et al., 2006). To illustrate, the moisture content in dried Channa punctatus was recorded to be 14.83\%-35.50\% (Flowra et al., 2012; Islam et al., 2013; Rana et al., 2019; Jahan \& Akhtar, 2019); 16.03\%-19.17\% in Channa striatus and 14.7\%-23.12\% in Wallago attu (Flowra \& Tumpa, 2012; Mansur et al., 2013; Majumdar et al., 2017) (Table 1). Notably, the moisture content in freshwater dried fishes in different locations of Bangladesh varied from 10.2\%-35.50\%. While, the moisture content in marine dried fishes ranged from $11.27 \%-39.59 \%$ (Table 2). The moisture percentage in marine dried Lalchoukya (Lutjanus johnii), Lalpoa (Johinus argentatus), Buna chingri (Penaeus monodon), and Riksha (Riksha sp) are 22.25\%, 21.92\%, $18.3 \%$ and $23.25 \%$, respectively (Paul et al., 2018). Furthermore, Azam et al. (2003) reported that the moisture content of fourteen selected dried fishes ranged from $18.23 \%$ to $23.61 \%$. Similarly, the moisture content of Loitta (Harpodon nehereus), Poa (Johnius dussumieri) and Churi (Lepturacanthus savala) were 22.22\%, 20.76\% and 13.81\%, respectively (Siddiqui et al., 2011). Remarkably, the moisture content varies with season and fish species. The high moisture content leads to bacterial and fungal attack and also insect infestation causing the reduction of product quality and safety. It is worth mentioning that, the high moisture content in dried product is due to improper drying, and the absorbance of atmospheric water from the surrounding environment during inappropriate packaging and storage (Rasul et al., 2018; Rasul et al., 2020).

Table 1. Proximate composition of freshwater dried fish from different regions of Bangladesh

\begin{tabular}{|c|c|c|c|c|c|c|}
\hline $\begin{array}{c}\text { Fish Species } \\
\text { (Local Name } \\
\text { and Scientific } \\
\text { Name) } \\
\end{array}$ & Location & $\begin{array}{l}\text { Moisture } \\
(\%)\end{array}$ & $\begin{array}{l}\text { Protein } \\
(\%)\end{array}$ & $\begin{array}{c}\text { Lipid } \\
(\%)\end{array}$ & $\begin{array}{c}\text { Mineral } \\
(\%)\end{array}$ & Reference \\
\hline \multirow{4}{*}{$\begin{array}{l}\text { Baim } \\
\text { (Mastacembelus } \\
\text { pancalus) }\end{array}$} & \multirow[b]{2}{*}{ Sylhet } & 19.84 & 56.34 & 5.60 & 16.08 & Hasan et al. (2018) \\
\hline & & 23.52 & 42.08 & 7.86 & 23.25 & Hasan et al. (2016) \\
\hline & Mymensingh & 26.42 & 51.23 & 10.58 & 12.20 & $\begin{array}{l}\text { Nurullah et al. } \\
\quad \text { (2006) }\end{array}$ \\
\hline & $\begin{array}{l}\text { Mymensingh } \\
\text { Rajshahi }\end{array}$ & $\begin{array}{l}26.42 \\
12.70\end{array}$ & $\begin{array}{l}44.72 \\
60.01\end{array}$ & $\begin{array}{l}16.63 \\
12.90\end{array}$ & $\begin{array}{l}12.21 \\
-\end{array}$ & $\begin{array}{l}\text { Hasan et al. (2006) } \\
\text { Sultana et al. }(2011)\end{array}$ \\
\hline \multirow{4}{*}{$\begin{array}{l}\text { Tengra } \\
\text { (Mystus vitatus) }\end{array}$} & Nilphamari & 18.20 & 44.08 & 17.76 & 20.08 & Flowra et al. (2012) \\
\hline & Sylhet & 21.43 & 54.65 & 6.01 & 15.76 & Hasan et al. (2016) \\
\hline & Gazipur & 12.44 & 61.32 & 11.65 & 14.54 & $\underset{(2018)}{\text { Majumdar et al. }}$ \\
\hline & Dhaka & 27.52 & 43.20 & 12.84 & 15.22 & Rana et al. (2019) \\
\hline Mola & Dhaka & 24.85 & 48.94 & 10.06 & 16.12 & Rana et al. (2019) \\
\hline
\end{tabular}




\begin{tabular}{|c|c|c|c|c|c|c|}
\hline $\begin{array}{l}\text { (Amblypharyngod } \\
\text { on mola) }\end{array}$ & Singra, Natore & 29.25 & 32.02 & 14.03 & 24.4 & Islam et al. (2013) \\
\hline \multirow{7}{*}{$\begin{array}{l}\text { Jat Puti } \\
\text { (Puntius sophore) }\end{array}$} & Rajshahi & 12.90 & 51.90 & 18.20 & - & Sultana et al. (2011) \\
\hline & Mymensingh & 26.02 & 49.20 & 10.76 & 19.32 & $\begin{array}{c}\text { Nurullah et al. } \\
\quad(2006)\end{array}$ \\
\hline & Mymensingh & 26.03 & 49.63 & 13.13 & 11.18 & Hasan et al. (2006) \\
\hline & Dhaka & 25.13 & 48.82 & 9.84 & 16.11 & Rana et al. (2019) \\
\hline & Savar, Dhaka & 40.93 & 32.61 & 12.28 & 10.81 & Huque et al. (2013) \\
\hline & Sylhet & 18.32 & 42.40 & 5.15 & 24.17 & Hasan et al. (2016) \\
\hline & Singra, Natore & 31.35 & 37.12 & 11.22 & 20.14 & Islam et al. (2013) \\
\hline $\begin{array}{l}\text { Puti (Barbides } \\
\text { sarana) }\end{array}$ & Mymensingh & 24.14 & 50.38 & 11.52 & 14.00 & $\begin{array}{l}\text { Nurullah et al. } \\
\qquad(2006)\end{array}$ \\
\hline \multirow{3}{*}{$\begin{array}{l}\text { Batashi } \\
\text { (Pseudeutropius } \\
\text { atherinoides) }\end{array}$} & Mymensingh & 26.26 & 48.60 & 8.40 & 17.80 & $\begin{array}{l}\text { Nurullah et } a l . \\
(2006)\end{array}$ \\
\hline & Rajshahi & 10.90 & 61.70 & 15.10 & - & Sultana et al. (2011) \\
\hline & Dhaka & 27.05 & 45.80 & 11.80 & 15.00 & Rana et al. (2019) \\
\hline \multirow{3}{*}{$\begin{array}{l}\text { Chapila } \\
\text { (Gudusia chapra) }\end{array}$} & Dhaka & 27.32 & 49.60 & 08.76 & 14.31 & Rana et al. (2019) \\
\hline & Mymensingh & 26.24 & 51.48 & 9.21 & 13.45 & $\begin{array}{c}\text { Nurullah et al. } \\
\qquad(2006)\end{array}$ \\
\hline & Dhaka & 28.20 & 49.84 & 09.15 & 12.63 & Rana et al. (2019) \\
\hline \multirow{5}{*}{$\begin{array}{l}\text { Katchki } \\
\text { (Corica soborna) }\end{array}$} & Rajshahi & 12.0 & 61.60 & 22.70 & - & Sultana et al. (2011) \\
\hline & Mymensingh & 27.33 & 52.75 & 8.91 & 11.00 & Hasan et al. (2006) \\
\hline & Nilphamari & 24.58 & 49.95 & 8.20 & 21.8 & Flowra et al. (2012) \\
\hline & Dhaka & 35.50 & 42.06 & 4.20 & 18.24 & Rana et al. (2019) \\
\hline & $\begin{array}{l}\text { Chalan beel, } \\
\text { Natore }\end{array}$ & 14.83 & 57.50 & 3.10 & 21.00 & $\begin{array}{c}\text { Jahan and Akhtar } \\
\qquad(2019)\end{array}$ \\
\hline \multirow{4}{*}{$\begin{array}{l}\text { Taki } \\
\text { (Channa } \\
\text { punctatus) }\end{array}$} & Singra, Natore & 34.43 & 41.38 & 3.21 & 20.74 & Islam et al. (2013) \\
\hline & Sylhet & 21.43 & 54.65 & 6.01 & 15.76 & Hasan et al. (2016) \\
\hline & Nilphamari & 17.80 & 60.50 & 2.50 & 22.73 & Flowra et al. (2012) \\
\hline & Mymensingh & 19.17 & 62.85 & 4.92 & 4.92 & Mansur et al. (2013) \\
\hline \multirow[t]{3}{*}{$\begin{array}{l}\text { Shol } \\
\text { (Channa striatus) }\end{array}$} & Dhaka & 18.75 & 66.44 & 6.81 & 6.49 & $\begin{array}{c}\text { Majumdar } \boldsymbol{e t} \text { al. } \\
(2017)\end{array}$ \\
\hline & Singra, Natore & 16.03 & 33.23 & 8.96 & 13.72 & $\begin{array}{c}\text { Flowra and Tumpa } \\
\qquad(2012)\end{array}$ \\
\hline & Mymensingh & 23.12 & 49.23 & 11.00 & 18.89 & Mansur et al. (2013) \\
\hline \multirow[t]{2}{*}{$\begin{array}{l}\text { Boal (Wallago } \\
\text { attu) }\end{array}$} & Dhaka & 22.70 & 61.85 & 6.21 & 6.79 & $\begin{array}{c}\text { Majumdar et al. } \\
\text { (2017) }\end{array}$ \\
\hline & Singra, Natore & 14.70 & 28.20 & 15.86 & 13.33 & $\begin{array}{l}\text { Flowra and Tumpa } \\
\qquad(2012)\end{array}$ \\
\hline $\begin{array}{l}\text { Rui } \\
\text { (Labeo rohita) }\end{array}$ & Mymensingh & 20.27 & 59.32 & 9.32 & 12.89 & Mansur et al. (2013) \\
\hline \multirow{2}{*}{$\begin{array}{l}\text { Bele } \\
\text { (Glossogobius } \\
\text { giuris) }\end{array}$} & Dhaka & 21.93 & 62.83 & 5.98 & 7.83 & $\begin{array}{c}\text { Majumdar et al. } \\
\text { (2017) }\end{array}$ \\
\hline & Singra, Natore & 33.84 & 38.96 & 4.88 & 21.68 & Islam et al. (2013) \\
\hline
\end{tabular}




\begin{tabular}{|c|c|c|c|c|c|c|}
\hline $\begin{array}{l}\text { Tit puti } \\
\text { (Puntius ticto) }\end{array}$ & Singra & 12.13 & 47.32 & 9.47 & 11.27 & $\begin{array}{c}\text { Flowra and Tumpa } \\
(2012)\end{array}$ \\
\hline $\begin{array}{l}\text { Kholisa } \\
\text { (Trichogaster } \\
\text { fasciata) }\end{array}$ & Gazipur & 15.06 & 53.98 & 11.02 & 19.68 & Rasul et al. (2019) \\
\hline $\begin{array}{l}\text { Bata } \\
\text { Labeo bata) }\end{array}$ & Singra, Natore & 12.35 & 45.72 & 5.38 & 10.78 & $\begin{array}{c}\text { Flowra and Tumpa } \\
\qquad(2012)\end{array}$ \\
\hline $\begin{array}{l}\text { Icha } \\
\text { (Palaemon sp.) }\end{array}$ & Singra, Natore & 18.18 & 51.19 & 11.53 & 15.67 & $\begin{array}{c}\text { Flowra and Tumpa } \\
\qquad(2012)\end{array}$ \\
\hline $\begin{array}{l}\text { Silver carp } \\
\text { (Hypophthalmicht } \\
\text { hys molitrix) }\end{array}$ & Gazipur & 25.43 & 61.51 & 6.21 & 6.79 & Rasul et al. (2018) \\
\hline $\begin{array}{l}\text { Chanda } \\
\text { (Chanda baculis) }\end{array}$ & Rajshahi & 10.20 & 52.20 & 13.10 & - & Sultana et al. (2011) \\
\hline $\begin{array}{l}\text { Lal Chanda } \\
\text { (Chanda ranga) }\end{array}$ & Rajshahi & 13.80 & 51.50 & 12.20 & - & Sultana et al. (2011) \\
\hline $\begin{array}{l}\text { Nama Chanda } \\
\text { (Chanda nama) }\end{array}$ & Nilphamari & 21.80 & 48.10 & 15.01 & 18.90 & Flowra et al. (2012) \\
\hline $\begin{array}{l}\text { Chela (Oxygaster } \\
\text { bacaila) }\end{array}$ & Rajshahi & 12.10 & 53.10 & 15.70 & - & Sultana et al. (2011) \\
\hline $\begin{array}{l}\text { Dhela } \\
\text { (Osteobrama } \\
\text { cotio) }\end{array}$ & Mymensingh & 23.26 & 52.20 & 9.50 & 16.00 & $\begin{array}{l}\text { Nurullah et al. } \\
\quad \text { (2006) }\end{array}$ \\
\hline
\end{tabular}

\section{Protein and amino acids in dried fish and their health benefits}

Fish is a good source of animal protein which has greater satisfying effect than other animal protein sources like beef and chicken (Uhe et al., 1992; Mohanty et al., 2019). Dried fish provides an excellent source of protein. Glover- Amengor et al. (2012) indicated that the dried fish powders could serve as good sources of protein and iron for the low income group. According to Glover-Amengor et al. (2012), the protein levels varied from $44.83 \%$ to $72.29 \%$ in some dried underutilized fish species. Normally, the sun-dried fishes contain $60 \%$ to $80 \%$ protein (Haque, 2004).

Sultana et al. (2011) stated that the protein content ranged from 51.5\%-61.6\% in seven SIS dried fish (Table 1). The protein varied between $44.08 \%$ to $65.65 \%$ in dried Mystus vittatus, Channa punctatus, Chanda nama, Corica soborna and Trichuirus haumela (Flowra et al., 2012). Besides, Rana et al. (2019) found that the protein content in ten indigenous dried fish varied from $42.06 \%$ to $65.78 \%$. The protein content was found in the range of $32.02 \%$ to $41.38 \%$ in dried Puntius sp. (puti), Amblypharyngodon mola (mola), Channa punctatus (taki) and Glossogobius giuris (bele) (Islam et al., 2013). The crude protein content of some freshwater dried fish ranged from 32.02\%-66.44\% (Table 1). According to Ullah et al. (2016), protein varied from $27.46 \%$ to $56.84 \%$ in ten different freshwater dried fish in North East India. Therefore, the dried fish of Bangladesh contain higher protein content than those of India. The comparatively protein rich dried fishes are Channa striatus, Channa punctatus, Corica soborna, Pseudeutropius 
atherinoides, Mastacembelus armatus, Glossogobius giuris, Labeo rohita, and Hypophthalmichthys molitrix etc. They contain more than $55 \%$ protein. In case of marine dried fish, Azam et al. (2003) reported the biochemical assessment of fourteen selected dried fish and found the protein content varied between $40.69 \%$ and $66.52 \%$. The crude protein content of marine dried fish ranged from $32.25 \%$ to $68.09 \%$ (Table 2). The crude protein content of dried Stromateus chinensis, S. cinereus, Riksha sp., Johinus argentatus, Trichiurus haumela, Harpodon neherus, Lutianus johnii and Penaeus sp. ranged from $33.56 \%$ to $58.22 \%$ with the highest content in shrimp and the lowest in the red snapper (Paul et al., 2018). Pravakar et al. (2013) reported that the mean value of protein content of Chinese pomfret (Stromateus chinensis) and Ribbon fishes (Trichiurus haumela) collected from Cox's Bazar were $60.03 \%$ and $54.36 \%$, respectively. Siddique et al. (2011) noted that the protein level of three marine dried fishes (Harpodon nehereus, Johnius dussumieri and Lepturacanthus savala) varied from 58.33\%-51.98\%, 64.39\%$56.46 \%$ and $71.90 \%-67.22 \%$, respectively. It was found that the protein content in fish might vary with respect to species due to certain factors, such as the season of the year, effect of spawning and migration, food availability etc. (Effiong and Tafa, 2005).

Dried fish is a cheaper and exceptional source of protein and necessary amino acids with fewer calories than other foods such as beef (Jonsson et al., 2007; Hassan et al., 2014). One hundred grams of dried fish contain around $80 \%$ protein with 300 calories against animal meat, which contains double the calorie and far less protein (Legacy Food Storage, 2016). Those proteins are a key source of antibodies and enzymes for all living beings, that make up an essential part of muscles, hair and other body components. Dried fish contain all the essential amino acids including sulphur containing amino acids as cysteine and methionine which are absent in plant protein (Bindu, 2005; Atowa et al., 2014) and methionine and lysine that are absent in terrestrial meat proteins (Tacon and Metian, 2013). Fish and dried fish protein are of high quality and contains sufficient amounts of all the essential amino acids required for body growth, maintenance of lean muscle tissues and active metabolism, repairing worn out tissues, and they contribute to the prevention of some diseases (Talabi 1995; Pal et al., 2018; Dale et al., 2019). In addition, proteins, peptides and amino acids from fish and fish products have recently become well known for their positive health effects (Rudkowska et al., 2010; Pilon $\boldsymbol{e t}$ al., 2011) though some amino acids reduction occurred in dried fish during drying and storage (Atowa et al., 2014). Nevertheless, Wu and Mao (2008) reported that there was no effect of the drying method on the amino acid composition of grass carp (Ctenopharyngodon idella) fillets. In addition, aquatic protein is highly digestible and rich in several peptides and essential amino acids such as methionine and lysine that are limited in terrestrial meat proteins (Tacon \& Metian, 2013). It is noteworthy to mention that, during drying, the digestibility of protein reduces slightly as IVPD (\%) remains lower (Atowa et al., 2014). On the other hand, it has been investigated that when fish 
proteins are warmed at a temperature below $100^{\circ} \mathrm{C}$, protein digestibility is not affected (Opstvedt, 1998). Madani et al. (2012) suggested that the dietary sardine protein acts as a possible prophylaxis against insulin resistance. Thus, the dried sardine could lower insulin resistance, improve hyperglycemia and decrease adipose tissue oxidative stress. It has been shown in human macrophages that fish protein hydrolysates decreased tumor necrosis factor a (TNF $\alpha$ ) (Rudkowska et al., 2010). Additionally, the sardine protein has potentials of lowering the effects on cardiovascular risk (Balfego et al., 2016). In addition, angiotensin-I converting enzyme (ACE) inhibition substances were determined in the tuna muscle protein (Kohama et al., 1988) and in the krill muscle protein (Kawamura et al., 1992) which have positive effect in reducing blood pressure of human. Hence, it is clear that small portions of dried fish can meet the need of proteins in the body aligned with positive health effects.

Table 2. Proximate composition of marine dried fish from different regions of Bangladesh

\begin{tabular}{|c|c|c|c|c|c|c|}
\hline $\begin{array}{l}\text { Fish Species } \\
\text { (Local Name and } \\
\text { Scientific Name) }\end{array}$ & Location & $\begin{array}{l}\text { Moisture } \\
(\%)\end{array}$ & $\begin{array}{l}\text { Protein } \\
(\%)\end{array}$ & $\begin{array}{l}\text { Lipid } \\
(\%)\end{array}$ & $\begin{array}{c}\text { Mineral } \\
(\%)\end{array}$ & Reference \\
\hline \multirow[t]{2}{*}{$\begin{array}{l}\text { Churi (Trichuirus } \\
\text { haumela) }\end{array}$} & Nilphamari & 14.10 & 65.65 & 11.8 & 9.63 & $\begin{array}{l}\text { Flowra et al. } \\
\text { (2012) }\end{array}$ \\
\hline & Cox's Bazar & 23.20 & 54.36 & 11.45 & 11.05 & $\begin{array}{l}\text { Pravakar et al. } \\
(2013)\end{array}$ \\
\hline $\begin{array}{l}\text { Loitta (Harpodon } \\
\text { nehereus) }\end{array}$ & Chittagong & 22.22 & 58.33 & 7.78 & 7.56 & $\begin{array}{l}\text { Siddique et } a l . \\
\text { (2011) }\end{array}$ \\
\hline Poa (Johnius Dussumieri) & Chittagong & 20.76 & 64.39 & 5.54 & 6.37 & $\begin{array}{l}\text { Siddique et al. } \\
\text { (2011) }\end{array}$ \\
\hline $\begin{array}{l}\text { Churi (Lepturacanthus } \\
\text { Savala) }\end{array}$ & Chittagong & 13.81 & 71.90 & 7.79 & 4.86 & $\begin{array}{l}\text { Siddique et al. } \\
\text { (2011) }\end{array}$ \\
\hline $\begin{array}{l}\text { Rupchanda (Stromateus } \\
\text { chinensis) }\end{array}$ & Cox’s Bazar & 14.20 & 59.14 & 11.60 & 7.02 & $\begin{array}{l}\text { Pravakar et al. } \\
(\mathbf{2 0 1 3 )}\end{array}$ \\
\hline $\begin{array}{l}\text { Lalchoukya (Lutjanus } \\
\text { johnii) }\end{array}$ & Cox's Bazar & 22.25 & 30.15 & 11.8 & 32.25 & $\begin{array}{l}\text { Paul et al. } \\
\text { (2018) }\end{array}$ \\
\hline $\begin{array}{l}\text { Lalpoa (Johinus } \\
\text { argentatus) }\end{array}$ & Cox's Bazar & 21.92 & 38.75 & 2.85 & 23.8 & $\begin{array}{l}\text { Paul et al. } \\
\text { (2018) }\end{array}$ \\
\hline $\begin{array}{l}\text { Buna chingri (Penaeus } \\
\text { monodon) }\end{array}$ & Cox's Bazar & 18.30 & 62.15 & 7.80 & 14.83 & $\begin{array}{l}\text { Paul et al. } \\
\text { (2018) }\end{array}$ \\
\hline Riksha (Riksha sp) & Cox's Bazar & 23.25 & 45.75 & 5.77 & 27.25 & $\begin{array}{l}\text { Paul et al. } \\
(2018)\end{array}$ \\
\hline \multirow[t]{3}{*}{ Phasa (Setipinna phasa) } & Cox's Bazar & 22.14 & 52.82 & 10.40 & 15.17 & $\begin{array}{l}\text { Siddiky et al. } \\
\text { (2017) }\end{array}$ \\
\hline & Dhaka & 23.34 & 47.84 & 23.91 & 3.78 & $\begin{array}{l}\text { Bhuiyan et al. } \\
\text { (2009) }\end{array}$ \\
\hline & Kuakata & 24.46 & 62.36 & 3.67 & 9.51 & $\begin{array}{l}\text { Azam et al. } \\
(\mathbf{2 0 0 3})\end{array}$ \\
\hline $\begin{array}{l}\text { Banded Needle Fish } \\
\text { (Strongylura leiura) }\end{array}$ & Cox's Bazar & 22.10 & 50.16 & 9.18 & 17.57 & $\begin{array}{l}\text { Siddiky et al. } \\
\text { (2017) }\end{array}$ \\
\hline Coral (Lates calcarifer) & Cox's Bazar & 26.74 & 40.31 & 5.03 & 11.50 & $\begin{array}{l}\text { Hossain et al. } \\
\text { (2017) }\end{array}$ \\
\hline $\begin{array}{l}\text { Parshe } \\
\text { (Mugil cephalus) }\end{array}$ & Kuakata & 19.93 & 68.09 & 4.87 & 7.45 & $\begin{array}{l}\text { Azam et al. } \\
(\mathbf{2 0 0 3 )}\end{array}$ \\
\hline
\end{tabular}




\begin{tabular}{|c|c|c|c|c|c|c|}
\hline & Dhaka & 21.19 & 68.09 & 8.22 & 10.35 & $\begin{array}{l}\text { Hossain et al. } \\
\text { (2015) }\end{array}$ \\
\hline $\begin{array}{l}\text { Kamot (Scoliodon } \\
\text { sorrakowah) }\end{array}$ & Kuakata & 23.49 & 58.35 & 7.84 & 11.32 & $\begin{array}{l}\text { Azam et al. } \\
(\mathbf{2 0 0 3 )}\end{array}$ \\
\hline $\begin{array}{l}\text { Taposhi } \\
\text { (Polynemus paradiseus) }\end{array}$ & Kuakata & 21.65 & 57.25 & 8.95 & 12.14 & $\begin{array}{l}\text { Azam et al. } \\
(2003)\end{array}$ \\
\hline $\begin{array}{l}\text { Shamudrik baim } \\
\text { (Muraenesox bagio) }\end{array}$ & Kuakata & 20.98 & 56.77 & 11.19 & 9.98 & $\begin{array}{l}\text { Azam et al. } \\
(\mathbf{2 0 0 3 )}\end{array}$ \\
\hline $\begin{array}{l}\text { Potka (Chelonodon } \\
\text { patoca) }\end{array}$ & Kuakata & 23.31 & 57.51 & 9.69 & 7.22 & $\begin{array}{l}\text { Azam et al. } \\
(\mathbf{2 0 0 3 )}\end{array}$ \\
\hline $\begin{array}{l}\text { Kukurjib (Cynoglossus } \\
\text { bengalensis) }\end{array}$ & Kuakata & 21.7 & 54.86 & 11.44 & 11.85 & $\begin{array}{l}\text { Azam et al. } \\
(2003)\end{array}$ \\
\hline $\begin{array}{l}\text { Shaplapata (Himantura } \\
\text { walga) }\end{array}$ & Kuakata & 21.08 & 54.19 & 25.3 & 11.01 & $\begin{array}{l}\text { Azam et al. } \\
(2003)\end{array}$ \\
\hline $\begin{array}{l}\text { Folichanda (Stromateus } \\
\text { cinereus) }\end{array}$ & Cox's Bazar & 39.59 & 32.25 & 6.75 & 15.73 & $\begin{array}{l}\text { Hossain et al. } \\
\text { (2017) }\end{array}$ \\
\hline
\end{tabular}

\section{Lipids and fatty acids in dried fish and their health benefits}

Lipids are water-insoluble macro-biomolecules that are soluble in organic solvents and have a variety of biological roles ranging from fuel molecules, energy stores to components of membranes (Mohanty $\boldsymbol{e t}$ al., 2019). Fish and dried fish are comprised of lipids and fatty acids (Shah et al., 2009; Balange $\boldsymbol{e t}$ al., 2017). There was no significant effect of drying on the fatty acids profile and composition of the dried cod heads (Salaudeen, 2014). Dried fish may become a good source of EPA and DHA (Rasul $\boldsymbol{e} t$ al., 2021a). The previous authors found that the major fatty acids of solar dried Megalaspis cordyla are palmitic acid (16:0), stearic acid (18:0), oleic acid (18:1n-9), cetoleic acids (22:1n-11), EPA (20:5n-3) and DHA (22:6n-3), which are beneficial for human health (Table 3). Sultana et al. (2011) observed that the lipid content ranged from $12.2 \%-22.7 \%$ in seven SIS dried fish (Table 1). Whereas, lipid content varied from 4.20\% to $13.03 \%$ in ten indigenous dried fish (Rana et al., 2019). Also, Flowra et al. (2013) found that the lipid content of dried Mystus vittatus, Channa punctatus, Chanda nama, Corica soborna and Trichuirus haumela varied between $1.91 \%$ and $17.76 \%$. In another study, Majumdar et al. (2017) found that the lipid contents of dried W. attu, C. striatus and G. giuris were $6.21 \%, 6.81 \%$ and $5.98 \%$, respectively. The fat content in freshwater dried fishes varied between $3.10 \%$ and $22.7 \%$ (Table 1). The highest lipid content was found in dried Corica soborna and the lowest was found in Channa punctatus.

The lipid content varied from $2.74 \%$ to $15.44 \%$ in dried Stromateus chinensis, S. cinereus, Riksha sp., Johinus argentatus, Trichiurus haumela, Harpodon neherus, Lutianus johnii and Penaeus sp. from Cox'x Bazar (Paul et al., 2018). On the oter hand, Azam et al. (2003) found that the lipid content in some selected marine dried fishes ranged from $3.67 \%$ to $25.3 \%$. The lipid content in marine dried fishes collected from 
different regions in Bangladesh varied from 4.87\% (Mugil cephalus) to $23.91 \%$ Setipinna phasa (Table 2). Moreover, dried cod (Gadus morhua) head contained 27.7\% MUFA, 37.8\% PUFA, 10.4\% EPA and 19.8\% DHA (Salaudeen, 2014). Comparatively, marine dried fishes contain more lipid percentage than freshwater dried fishes. This is possibly related to the variation in initial lipid content of raw materials used for processing (Stansby, 1962) as fat content in fish may vary according to seasons, species, and age and maturity of the respective species (Piggot, 1990). Oxidation of lipids is another reason of variation in lipid content as the degree of lipid oxidation was reported to be high in traditional dried fish products available in Bangladesh (Majumdar et al., 2018; Rana et al., 2019; Rasul et al., 2020).

Fish lipids are known to provide high contents of important components for the human diet, such as essential fatty acids, n-3 polyunsaturated fatty acids (PUFA) that have shown a positive role in preventing certain human diseases, including cardiovascular ones (Simopoulos, 1999; Abeywardena \& Patten, 2011; Pal et al., 2018). Usually marine fish lipids, however, differ from the other lipids in that they contain longer-chain fatty acids, and a larger proportion of highly unsaturated fatty acids (Tilami \& Samples, 2017; Pal et al., 2018). Remarkably, the most beneficial omega-3s are EPA and DHA that are found in seafood and seafood products, and have several beneficial impacts on human health (Tir et al., 2017). These benefits include decreasing the risk of myocardial infarction (Bucher et al., 2002) and keeping the body's circulation functioning well (Weitz et al., 2010; Bowen et al., 2016). They, in addition, lower both blood pressure and triglyceride concentration in blood (Harris et al., 1997). Additionally, they enhance the immune system (Damsgaard et al., 2007), sustain proper brain function in human body (Pal $\boldsymbol{e t}$ al., 2018) and fight with diabetes and obesity (Legacy Food Storage, 2016). They also protect against various psychological disorders, , particularly, depression and the attention deficit hyperactivity disorder in addition to their efficacy to protect the body against cancer (Sinn, 2007). The DHA together with the EPA are preventive to several diseases like atherosclerosis, dementia, rheumatoid arthritis, alzheimer disease (AD), and age-related macular degeneration (AMD) (Connor, 2000; Calder, 2012; Hashimoto et al., 2015). It was found that free fatty acids, especially DHA content increased significantly during the drying period of the herring fillet, indicating partial hydrolysis of phospholipids (Shah et al., 2009). The consumption of long chain n-3 PUFA in pregnancy is also known to be linked with improved cognitive development scores (Swanson, et al., 2012; Kwasek et al., 2020). Dietary guidelines from the World Health Organization and the Dietary Reference Intakes recommend a total fat intake between 20\% and 35\% of total calories (FAO, 2010). In this case, dried fish is considered a good diet for human. 
Table 3. Fatty acid composition (mg/g dry matter) of total lipids in Megalaspis cordyla

(Rasul et al., 2021a)

\begin{tabular}{lc}
\hline Fatty acids & Solar dried M. cordyla \\
\hline $14: 0$ & $3.09 \pm 0.02$ \\
$16: 0$ & $10.32 \pm 0.04$ \\
$18: 0$ & $7.04 \pm 0.02$ \\
$20: 0$ & $0.27 \pm 0.01$ \\
$\Sigma$ saturated & $20.72 \pm 0.02$ \\
$14: 1 n-9$ & $0.16 \pm 0.01$ \\
$16: 1 n-9$ & $4.23 \pm 0.03$ \\
$18: 1 n-9$ & $7.04 \pm 0.03$ \\
$20: 1 n-9$ & $3.32 \pm 0.03$ \\
$22: 1 n-11$ & $32.58 \pm 0.33$ \\
$\Sigma$ monounsaturated & $47.33 \pm 0.34$ \\
$14: 2$ & $0.50 \pm 0.01$ \\
$16: 2$ & $2.92 \pm 0.03$ \\
$16: 3$ & $0.45 \pm 0.02$ \\
$18: 2 n-6$ & $1.00 \pm 0.01$ \\
$18: 3 n-6$ & $0.61 \pm 0.10$ \\
$18: 4 n-3$ & $0.66 \pm 0.06$ \\
$20: 3 n-6$ & $0.73 \pm 0.02$ \\
$20: 4 n-6$ & $1.31 \pm 0.02$ \\
$20: 5 n-3$ & $2.26 \pm 0.06$ \\
$22: 2$ & $3.29 \pm 0.02$ \\
$22: 3$ & $0.95 \pm 0.02$ \\
$22: 4 n-6$ & $3.31 \pm 0.12$ \\
$22: 6 n-3$ & $12.46 \pm 0.15$ \\
$\Sigma$ polyunsaturated & $30.45 \pm 0.36$ \\
Others & $1.50 \pm 0.03$ \\
\hline
\end{tabular}

\section{Mineral composition in dried fish and their health benefits}

Mineral ratios are often more important in determining nutritional deficiencies and excess; it is predictive of future or hidden metabolic disfunctions (Begum et al., 2017). Most fishes available in dried forms have less amounts of cholesterol and salt and great amounts of minerals that are necessary for the development of one's body and make fish unavoidable as healthy diet (Eyo, 2001). The mineral content of dried W. attu, C. striatus and G. giuris were 6.79\%, 6.49\% and 7.83\%, respectively (Majumdar et al., 2017). While, the mineral content ranged from $9.63 \%$ to $22.73 \%$ in five selected dried fish (Flowra et al., 2012), $10.78 \%$ (Labeo bata) to $15.67 \%$ (Palaemon sp.) in five traditionally dried fish (Puntius ticto, Labeo bata, Wallago attu, Channa striatus and Palaemon sp.) (Flowra \& Tumpa, 2012), 11.11 to $18.89 \%$ in Channa striatus, Wallago attu and Labeo rohota (Mansur et al., 2013). The mineral content ranged from $4.92 \%$ $24.4 \%$ in freshwater dried fishes (Table 1). This content in fourteen marine dried fishes ranged between $5.08 \%$ and $12.14 \%$ (Azam et al., 2003). The amount of minerals in dried marine fish ranged between $4.86 \%$ and $7.56 \%$ (Siddique et al., 2011), $11.50 \%$ in dried Lates calcarifer, and $15.75 \%$ in Stromateus cinensis (Hossain et al., 2017). It ranged from $3.78 \%-32.25 \%$ in marine dried fishes (Table 2). The variation in mineral contents is 
related to different locations, species, pre-treatments of raw materials with salt and herbal substance during drying (Paul et al., 2018).

It has been reported that the calcium percentages are high in Tengra (Mystus vittatus) $1.33 \%$ and low in Katchki (Corica soborna) $0.90 \%$. Phosphorus content is high in Lal chanda (Chanda ranga) $2.90 \%$ and low in Katchki (Corica soborna) $1.72 \%$ (Table 4). The higher amount of iron was found in Mola (Amblypharyngodon Mola)with a value of $44.90 \mathrm{mg} / 100 \mathrm{gm}$, whereas the lower amount was observed in Chela (Oxygaster bacaila), recording a value of $16.85 \mathrm{mg} / 100 \mathrm{~g}$ (Sultana et al., 2011). Comparatively, the small fish and their dried products are known to be a good source of minerals (Fawole et al., 2007; Roos et al., 2007). The calcium, iron and phosphorus content of the fish powder from the selected species varied from $2.49 \mathrm{~g} / \mathrm{kg}$ (L. rohita) to $2.55 \mathrm{~g} / \mathrm{kg}$ (small prawns), $0.043 \mathrm{~g} / \mathrm{kg}$ (H. molitrix and P. sophore) to $0.184 \mathrm{~g} / \mathrm{kg}$ (C. mrigala) and $0.94 \mathrm{~g} / \mathrm{kg}$ (L. rohita) to 1.91 $\mathrm{g} / \mathrm{kg}$ ( $P$. sophore), respectively (Jahan et al., 2017). The highest calcium content was found in small prawns $(2.54 \mathrm{~g} / \mathrm{kg})$ and the lowest in L. rohita $(2.48 \mathrm{~g} / \mathrm{kg})$ (Fig. 1). Another study reported that Cirrhina reba contained $822 \mathrm{mg}$ calcium/100g of fish (Islam et al., 2003) and dried tuna contained $844 \mathrm{mg}$ calcium $/ 100 \mathrm{gm}$ of fish (Thilsted $\boldsymbol{e t}$ al., 2014). The highest iron content was found in C. mrigala $(0.184 \mathrm{~g} / \mathrm{kg})$ and the lowest in $H$. molitrix and $P$. sophore $(0.043 \mathrm{~g} / \mathrm{kg})$. This difference could be attributed to the factors affecting the iron content such as species, individuals, and sampling periods (Yilmaz et al., 2010). The highest phosphorus content was found in $P$. sophore $(1.91 \mathrm{~g} / \mathrm{kg})$ and the lowest in L. rohita $(0.94 \mathrm{~g} / \mathrm{kg})$. Markedly, the burrito fish (Brachydeuterus auritus) contains $93.71 \mathrm{mg} / 100 \mathrm{~g}$ phosphorus (Abbey et al., 2017). The lowest value of phosphorus might be due to the removal of head, bones and scales from the fish body. Limited data have been found on other minerals in dried fish in Bangladesh. In addition, the presence of $\mathrm{Fe}, \mathrm{Ca}, \mathrm{K}, \mathrm{C}, \mathrm{S}, \mathrm{P}, \mathrm{Si}, \mathrm{Al}, \mathrm{Mg}, \mathrm{Na}$, and $\mathrm{O}$ were detected in ten dried fish samples in north east India (Ullah et al., 2016). Similarly, Akinneye et al. (2010) found K (250 mg), Na (218 mg), Mg (183 mg) and Ca (150 mg) in Sardinella sp. (oven dried) and $H$. niloticus (sun-dried).

Table 4. Mineral composition of freshwater dried SIS in Bangladesh (Sultana et al., 2011)

\begin{tabular}{|c|c|c|c|c|}
\hline $\begin{array}{c}\text { Fish species } \\
\text { (local name and scientific } \\
\text { name) }\end{array}$ & Location & $\begin{array}{c}\mathrm{Ca} \\
(\%) \mathrm{g}\end{array}$ & $\begin{array}{c}\mathbf{P} \\
(\%) \mathrm{g}\end{array}$ & $\begin{array}{c}\text { Fe } \\
\text { mg/100 } \\
\text { gm }\end{array}$ \\
\hline Chanda (Chanda baculis) & & 1.22 & 2.70 & 36.00 \\
\hline Lal chanda (Chanda ranga) & & 1.10 & 2.90 & 17.00 \\
\hline Tengra (Mystus vitatus) & & 1.40 & 2.80 & 31.20 \\
\hline $\begin{array}{c}\text { Mola (Amblypharyngodon } \\
\text { Mola) }\end{array}$ & Rajshahi & 1.18 & 2.20 & 44.90 \\
\hline Chela (Oxygaster bacaila) & & 1.16 & 2.60 & 16.85 \\
\hline $\begin{array}{c}\text { Batashi (Clupisoma } \\
\text { atherinoides) }\end{array}$ & & 0.99 & 1.80 & 34.90 \\
\hline Katchki (Corica soborna) & & 0.90 & 1.72 & 22.00 \\
\hline
\end{tabular}


Mineral contents in fish depend on its availability in their environment followed by diet absorptive capability and preferential accumulation of same by the fish (Adewoye \& Omotosho 1997; Ibiyo et al., 2006). Calcium plays an essential role in human body for the formation of bones, muscle tone and nervous impulse (Molla et al., 1998) and it also helps in blood clotting, muscle contraction, osmoregulation. Moreover, calcium acts as a cofactor for enzymatic procession (Lovell, 1989). Phosphorous helps in many physiological processes, such as activity of adinosine polyphosphates and phospholipids (Nair \& Mathew, 2001), regulation of the whole-body acid-base balance and as a major constituent of teeth and bone (EFSA, 2006). Potassium helps in normal functioning of nerves, muscle and heart, sugar metabolism, acid-base balance, oxygen of brain. Numerous aspects of cellular metabolism are zinc dependent. It supports the function of some proteins in the body. Zinc helps to strengthen their defense against free radical attack and assists in the work of the immune system and in growth and development (Jónsson et al., 2007). Iron prevents anemia (Demirezen, 2006) and dried fish is one of the major sources of iron for adults and children. With iron, copper catalyses oxidationreduction mechanisms and tissue respiration. Manganese is needed for growth and good health, and its deficiency can cause nervous problem (Demirezen, 2006).

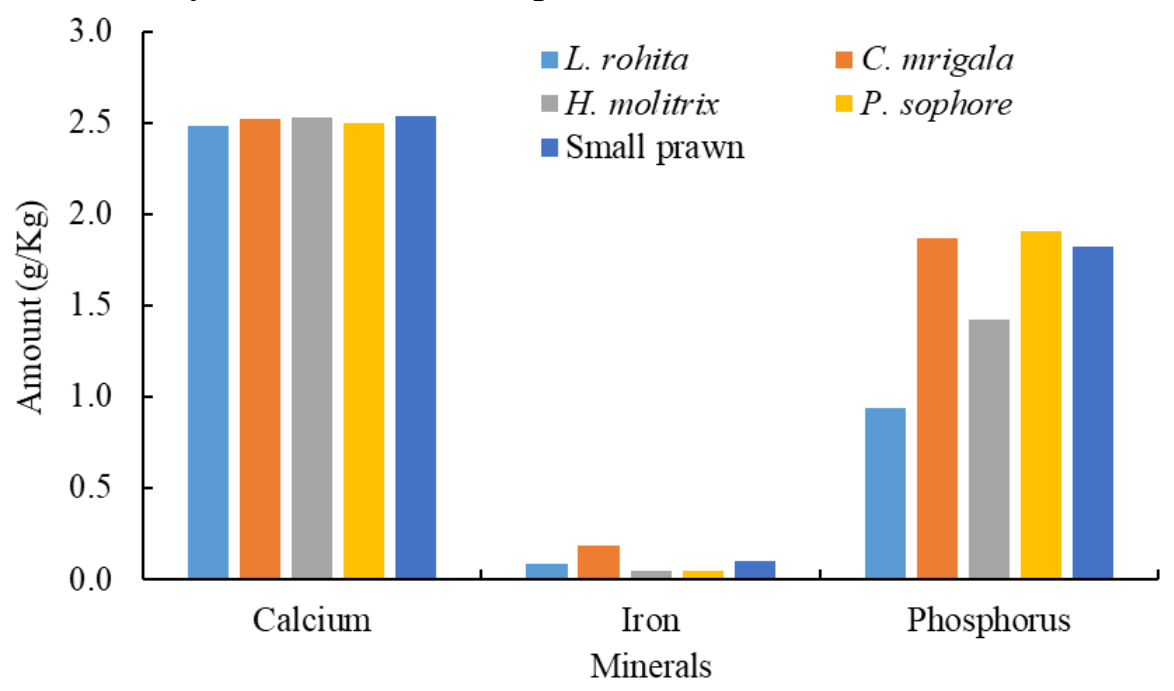

Fig. 1. Mineral content of dried fish powder from different fish species and small prawns (Jahan et al., 2017)

\section{CONCLUSION}

Dried fish is a natural product and important source of protein, lipids and acts as a better nutrient source compared to the fresh fish for many developed and developing countries, and particularly for individuals with low income. It plays an important role in improving food security and nutritional status. This food item is regarded as most ecofriendly and the healthiest one for humans. 


\section{REFERENCES}

Abbey, L.; Amengor, M.G.; Atikpo, M.O.; Atter, A. and Toppe, J. (2017). Nutrient content of fish powder from low value fish and fish byproducts. Food Sci. Nutr., 5(3):374-379.

Ahmed, T.; Mahfuz, M,; Ireen, S.; Ahmed, A.M.S.; Rahman, S.; Islam, M.M.; Alam, N.; Hossain, M.I.; Rahman, S.M.M.; Ali, M.M.; Choudhury, F.P. and Cravioto, A. (2012). Nutrition of children and women in Bangladesh: Trends and directions for the future. J. Health Popul. Nutr., 30(1): 1-11. doi: 10.3329/ jhpn. v30i1. 11268

Alam, A.K.M.N. (2010). Post-harvest loss reduction in fisheries in Bangladesh: A way forward to food Security. National Food Policy Capacity Strengthening Programme. Final Report PR\# 5/08. p. 171. Please visit: http://fpmu.gov.bd/agridrupal/ sites/ default/files/Nowsad_Alam-PR5-08.pdf

Abdullahi, S.A. (2001). Investigation of nutritional status of Chrysichthys nigrodigitatus, Bayrus filamentous and Auchenoglanis occidentals' family Barigdae. J. Aid zone fish., 1: 39-50.

Arannilewa, S.T.; Salawu, S.O.; Sorungbe, A.A. and Ola-Salawu, B.B. (2006). Effect of frozen period on the chemical, microbiological and sensory quality of frozen Tilapia fish (Sarotherodun galiaenus). Nutr. health., 18(2): 185-192.

Adewoye, S.O. and Omotosho, J.S. (1997). Nutrient composition of some freshwater fishes in Nigeria. Biosci. Res. Commun., 11: 333-336.

Akinneye, J.O.; Amoo, I.A. and Bakare, O.O. (2010). Effect of drying methods on the chemical composition of three species of fish (Bonga spp., Sardinella spp. and Heterotis niloticus). African J. Biotech., 9 (28): 4369-4373

Abeywardena, M.Y. and Patten, G.S. (2011). Role of $\omega 3$ longchain polyunsaturated fatty acids in reducing cardio-metabolic risk factors. Endocr. Metab. Immune., 11(3): 232-246.

Atowa, C. O.; Nwabu, A. O. and Ogiedu, T. A. (2014). Storage and drying time Effects on digestibility and amino acid composition of dried smoked Horse Mackerel (Trachurus Trachurus) Fillets. Int. J. Food Eng., 4(4): 98-105

Azam, K.; Basher, M.Z.; Asaduzzaman, M.; Hossain, M.H. and Ali, M.Y. (2003). Biochemical quality assessment of fourteen selected dried fish. Uni. J. Zool., 22: 23-26.

Balachandran, K. K. (2001). Post-harvest Technology of Fish and Fish Products, Daya Publishing House, Delhi.

Balange, A.K.; Xavier, K.A.M.; Kumar, S.; Nayak, B.B.; Venkateshwarlu, G. and Shitole, S.S. (2017). Nutrient profiling of traditionally sun-dried Acetes. Indian J. Fish., 64 (Special Issue): 264-267.

Balfego, M.; Canivell, S.; Hanzu, F.A.; Sala-Vila, A.; Martinez-Medina, M.; Murillo, S.; Mur, T.; Ruano, E.G.; Linares, F.; Porras, N.; Valladares, S.; Fontalba, M.; Roura, E.; Novials, A.; Hernandez, C.; Aranda, G.; Siso-Almirall, A.; Rojo- 
Martinez, G.; Simo, R. and Gomis, R. (2016). Effects of sardine-enriched diet on metabolic control, inflammation and gut microbiota in drug-naive patients with type 2 diabetes: A pilot randomized trial. Lipids in Health and Dis., 15: 70-78.

Begum, M.; Akter, T. and Minar, M.H. (2012). Effect of salt and garlic on the quality and microbial content of smoked catfish (Pangasianodon hypophthalmus). Int. J. Bio. res. Stress Manage., 3(4) 464-467.

Begum, M.; Nabila, N.M.; Latifa, G.; Shubhash, C.C. and Binte, F.F. (2017). Effect of salt and turmeric treated smoke drying method on the sensory, proximate, chemical and microbial quality of G. chapra, X. cancila and M. pancalus fish. Int. J. Adv. Educ. Res., 2, 20-25.

Bhuiyan, M.N.H.; Dawlatana, M.; Bhuiyan, H.R.; Lucky, F.A.; Saha, B.K. and Bhuiyan, M.N.I. (2009). Quality assessment of dry fishes of Bangladesh with the special emphasis on harmful additives. Bangladesh J. Sci. Indus. Res., 44(3): 311-318.

Bindu, J. (2005). Packaging of Dried Fish; Central Institute of Fisheries Technology: Kochi, pp 152-156. http://hdl.handle.net/123456789/1085

Bowen, K.J.; Harris, W.S. and Kris-Etherton, P.M. (2016). Omega-3 Fatty Acids and Cardiovascular Disease: Are There Benefits? Curr. treat. options cardiovasc. med., 18(11): 60-69. https://doi.org/10.1007/s11936-016-0487-1

Bucher, H.C.; Hengstler, P.; Schindler, C. and Meier, G. (2002). N-3 polyunsaturated fatty acids in coronary heart disease: a meta-analysis of randomized controlled trials. Am. J. med., 112(4): 298-304.

Calder, P.C. (2012) The role of marine omega-3 (n-3) fatty acids in inflammatory processes, atherosclerosis and plaque stability. Mol. Nutr. Food. Res., 56(7): 1073-1080

Connor, W.E. (2000). Importance of n-3 fatty acids in health and disease. Am. J. Clinic. Nutr., 71(1): 171-175.

Damsgaard, C.T.; Lauritzen, L.; Kjær, T.M.; Holm, P.M.; Fruekilde, M.B.; Michaelsen, K.F. and Frøkiær, H. (2007). Fish oil supplementation modulates immune function in healthy infants. J. Nutr., 137(4): 1031-1036.

Dale, H.F.; Madsen, L. and Lied, G.A. (2019). Fish-derived proteins and their potential to improve human health. Nutr. Rev., 77(8): 572-583 doi: 10.1093/nutrit/nuz016

Demirezen, D. and Uruc, K. (2006). Comparative study of trace elements in certain fish, meat and meat products. Meat Sci. 74(2): 255-260

DoF. (2018). Yearbook of Fisheries Statistics of Bangladesh, 2017-18. Fisheries Resources Survey System (FRSS), Department of Fisheries. Bangladesh: Ministry of Fisheries, 2018. Volume 35 : p. 129.

Effiong, B.N. and Fakunle, J.O. (2011). Proximate and mineral composition of some commercially important fishes in Lake Kainji. Nig. J. Basic Appl. Sci., 1: 2497- 2500.

Effiong, B.N. and Tafa, J.L. (2005). Proximate composition of nutrients in adult Clarias gariepinus, Heterobranchus longifilis and their hybrid,"Proceedings of the 20th Annual conference of Fisheries Society of Nigeria, 14th-18th Nov., pp. 550-553. 
EFSA (European Food Safety Authority). (2006). Tolerable upper intake levels for Vitamin and Minerals. Scientific committee on food; scientific panel on dietetic products, nutrition and allergies. Please visit:

http://www.efsa.europa.eu/sites/default/files/efsa_rep/blobserver_assets/ndatolerableuil.p df

Eyo, A.A. (2001). Fish processing Technology in the tropics. National Institute for Freshwater Fisheries Research. University of Ilorin press, pp 66-70.

Fawole, O.O.; Ogundiran, M.A.; Ayandiran T.A. and Lagunju, O.F. (2007). Proximate and mineral composition of some selected fresh water fishes in Nigeria. Int. J. Food Safe., 9:52-55.

Flowra A.F. and Tumpa S.A. (2012). Chemical composition of five selected dry fish species in Chalan Beel, Bangladesh. DAV. Int J. Sci. India, 1(2): 157-160.

Flowra, F.A.; Tumpa, A.S. and Islam, M.T. (2012). Biochemical analysis of five dried fish species of Bangladesh. Univ. J. Zool, Rajshahi Univ., 31: 09-11.

FAO (Food and Agricultural Organization). (2010). Fats and fatty acids in human nutrition. Report of an expert consultation, 10-14 November 2008, Geneva.

Glover-Amengor, M.; Atikpo, M.A.O.; Abbey, L.D.; Hagan, L.; Ayim, J. and Toppe, J. (2012). Proximate composition and consumer acceptability of three underutilised fish species and tuna frames. World Rural Observ., 4:65-70.

Harris, W.S.; Lu, G.; Rambjør, G.S.; Wõlen, A.I.; Ontko, J.A.; Cheng, Q. and Windsor, S.L. (1997). Influence of n-3 fatty acid supplementation on the endogenous activities of plasma lipases. Am. J. Clinic. Nutr., 66(2): 254-260.

Hasan, M.M.; Shikha, F.H.; Hossain, M.I.; Kamal, M.; Islam, M.N. and Wahab, M. A. (2006). Quality assessment of traditional, rotary and solar tunnel dried small indigenous fish species products. Bangladesh J. Fish. Res., 10(1): 73-84.

Hasan, M.M.; Rasul, M.G.; Ferdausi, H.J.; Trina, B.D.; Sayeed, A.; Shah, A.K.M.A. and Bapary, M.A.J. (2016). Comparison of organoleptic and chemical characteristics of some traditional and improved dried fish products. Res. J. Ani. Vet. Fish. Sci., 4(2): 1-6.

Hoq, E. (2004). Bangladesher Chhoto Mach (A book on small indigenous fish species of Bangladesh). Published by Graphic Sign, Mymensingh, 2200, pp. 81-84.

Hasan, M.M.; Sayeed, M. A.; Khalil, I.; Kumar, K.; Tikadar, N.K.C. and Ahmed, Z. (2018). Nutritional quality assessment of dried baim fishes in Sylhet Sadar Upazila. Int. J. Fish. Aqua. Stu., 6(5): 363-367.

Hassan, Z.M.; Sulieman, A.M.E. and Elkhalifa, E.A. (2014). Nutritional value of Kejeik: A dry fish product of the Sudan. Pak. J. Biol. Sci., 17: 1115-1123. DOI: 10.3923/ pjbs.2014.1115.1123.

Hashimoto, M.; Katakura, M.; Tanabe, Y.; Mamun, A.A.; Inoue, T. and Hossain, S. (2015). n3 fatty acids effectively improve the reference memory-related learning ability associated with increased brain docosahexaenoic acid-derived docosanoids in aged rats. BBA - Mol. Cell. Biol. L., 1851(2): 203-209. 
Hossain, M.M.; Hossain, M.D.; Noor, M.A.; Haque, A.S.M.T. and Kabir, M.A. (2015). Quality aspects of some dried fish products collected from different super shops of Dhaka city in Bangladesh. J. Sylhet Agril. Univ., 2(2):283-287.

Hossain, M.N.; Jamil, M.G.M.; Mia, M.M.; Uddin, M.N. and Mansur, M.A. (2017). Studies on the proximate composition, quality and heavy metal concentration of two sundried marine fish (Sun-Dried Silver Pomfret and Sun-Dried Perch) of Cox's Bazar district of Bangladesh. J. Environ. Sci. Natural Res., 10(1): 25-32.

Huque, R.; Islam, M. and Khatun, A. (2013). Microbiological quality improvement of dried fish by gamma irradiation and assessment of food value upon irradiation with respect to biochemical aspect. Int. Res. J. Pharma. Appl. Sci., 3(2), 1-5.

Ibiyo, I.M.; Atteh, J.O.; Omotosho, J.S.; Madu, C.T.; Okaeme, A.N. and Ibiwoye, T.I.I. (2006). Some pathological changes resulting from vitamin C deficiency in Heterobranchus longifilis fingerlings. Nig. J. Fish., 2 (3): 7-15.

Islam, M.A.; Mohsin, A.B.M.; Bhuiyan, A.S. and Absar, N. (2003). Biochemical composition and nutritional value of Cirrhina reba (Hamilton, 1822) of Bangladesh. J. bio-sci., 11: 127-130.

Islam, M.T.; Ahmed, S.; Sultana, M.A.; Tumpa, A.S. and Flowra, F.A. (2013). Nutritional and food quality assessment of dried fishes in Singra Upazila under Natore district of Bangladesh. Trends fish. res., 2(1): 2319-2325.

Jahan, S.N. and Akhtar, S. (2019). Quality assessment of oven dried and traditional sun dried Channa Punctatus. Int. J. Food Sci. Biotech., 4(4): 94-99.

Jahan, S.N.; Bayezid, M.A., Islam, M.A.; Siddique, M.A.B.; Karmokar, P.K. and Flowra, F.A. (2017). Biochemical quality assessment of fish powder. Am. J. Food Nutr., 5 (3): 110-114. doi: 10.12691/ajfn-5-3-6.

Jain, D. and Pathare, P.B. (2007). Study the drying kinetics of open sun drying of fish. J. Food Eng., 78(4): 1315-1319.

Jonsson, A.; Finnbogadottir, G.A.; Porkelsson, G.; Magnusson, H.; Reykdal, O. and Arason, S. (2007). Dried fish as health food: Report. Matis Food Research. Innov. Saf., $32(7): 1-6$

Kar, M.; Hoq, M.E.; Islam, M.S.; Islam, M.M.; Meghla, N.T.; Suravi, and Kabir, M.H. (2020). Monitoring of proximate composition, heavy metal concentrations and pesticide residues in marine fish available in the coastal region of Bangladesh. Grassroots J. Natural Resources, 3(2): 30-41.

Kawamura, Y.; Sugimoto, T.; Takane, T. and Satake, M. (1992). Physiologically active peptide motification in proteins, peptide inhibitor of ACE from the hydrolysates of antarctic krill muscle protein. Jpn. Agric. Res. Q., 26 (3): 210-213.

Khan, M.A.A. and Khan, Y.S.A. (2001). Insect's infestation and preventive measures in dry fish storage of Chittagong, Bangladesh. J. Biol. Sci., 1: 963-965. 
Koffi-Nevry, R.; Ouina, T. S. T.; Koussemon, M. and Brou, K. (2011). Chemical composition and lactic microflora of Adjuevan, a traditional ivorian fermented fish condiment. Pak. J. Nutr., 10: 332-37. https://doi.org/10.3923/pjn.2011.332.337

Kohama, Y.; Matsumoto, S.; Oka, H.; Terramoto, T.; Okabe, M. and Mimura, T. (1988). Isolation of angiotensin converting enzyme inhibitor from tuna muscle. Biochem. Biophys. Res. Comm., 155: 332- 337.

Kwasek, K.; Thorne-Lyman, A.L. and Phillips, M. (2020). Can human nutrition be improved through better fish feeding practices? a review paper. Critical reviews in food science and nutrition, 28(4): 449-458.

Legacy Food Storage. http://babellfs.blogspot.com/2016/02 2016 (Access on 19th August, 2020).

Li, D.; Bode, O.; Drummond, H. and Sinclair, A.J. (2003). Omega-3 (n-3) fatty acids. In F. D. Gunstone (Ed.), Lipids for functional foods and nutraceuticals Bridg water, England: The Oily Press. pp. 225-262.

Lovell, R.T. (1989). Nutrition and Feeding of Fish. Van Nostrand Reinhold, New York, $260 \mathrm{pp}$.

Madani, Z.; Louchami, K.; Sener, A.; Malaisse, W.J. and Yahia, D.A. (2012). Dietary sardine protein lowers insulin resistance, leptin and TNF-alpha and beneficially affects adipose tissue oxidative stress in rats with fructose-induced metabolic syndrome. Int. J. Mol. Med., 29: 311-318.

Majumdar, B.C.; Afrin, F.; Rasul, M.G.; Khan, M. and Shah, A.K.M.A. (2017). Comparative study of physical, chemical, microbiological and sensory aspects of some sun dried fishes in Bangladesh. Braz. J. Biol. Sci., 4(8): 323-331.

Majumdar, B.C.; Afrin, F.; Rasul, M.G.; Shaha, D.C. and Shah, A.K.M.A. (2018). Changes in physicochemical, microbiological, and sensory properties of sun-dried mystus vittatus during storage at ambient temperature. Fishes, 3(3), 32.

Mansur, M.A.; Rahman, S.; Khan, M.N.A.; Reza, M.S. and Uga, S. (2013). Study on the quality and safety aspect of three sun-dried fish. Afr. J. Agric. Res., 8(41): 5149-5155. Mohanty, B.P.; Ganguly, S.; Mahanty, A.; Mitra, T.; Patra, S.; Karunakaran, D.; Mathew, S.; Chakraborty, K.; Paul, B.N. and Sarma, D. (2019). Fish in Human Health and Nutrition. Advances in Fisheries Research, Narendra Publishing House, Delhi. pp. 189-218.

Mollah, A.H.; Rahman, M.S. and Alam, M.T. (1998). Study on proximate chemical analysis of Bangladeshi freshwater fish Rita rita (Ham.) and seasonal variation of lipid, protein and related substances. Univ. j. zool., Rajshahi Univ.,17: 1-6

Nair, P.G.V. and Mathew, S. (2001). Biochemical composition of fish and shell fish, Central Institute of Fisheries Technology, Cochin-682029, ICAR.

Nowsad, A.K.M. (2005). Participatory Training of Trainers: A New Approach Applied in Fish Processing. 1st ed; Bangladesh Fisheries Research Forum. 
Nurullah, M.; Kamal, M.; Wahab, M.A.; Islam, M.N.; Reza, M.S.; Thilsted, S.H. and Mazid, M.A. (2006). Quality assessments of traditional and solar tunnel dried SIS (Small Indigenous Fish Species) products. Bangladesh J. Fish. Res., 10(1): 63-72.

Opstvedt, J. (1998); Influence of drying and smoking on protein quality. In fish drying and smoking; Elsevier Applied Science: Essex. UK, pp 23.

Pal, B.N.; Shukla, A.K.; Maurya, and Verma, H.O. (2018). A review on role of fish in human nutrition with special emphasis to essential fatty acid. Int. J. Fish. Aqua. Stu., 6(2): 427-430.

Paul, P.C.; Reza, M.S.; Islam, M.N. and Kamal, M. (2018). Quality assessment of traditionally dried marine fish of Bangladesh. Asian Food Sci. J., 5: 1-11.

Pilon, G.; Ruzzin, J.; Rioux, L. E.; Lavigne, C.; White, P. J.; Froyland, L.; Jacques, H.; Bryl, P.; Beaulieu, L. and Marette, A. (2011). Differential effects of various fish proteins in altering body weight, adiposity, inflammatory status, and insulin sensitivity in high-fat-fed rats. Metab.-Clin. Exper., 60: 1122-1130.

Piggot, G.M. and Tucker, B.W. (1990). Seafood: Effects of Technology on Nutrition. New York, USA: Marcel Dekker, Inc. pp. 102-126.

Pravakar, P.; Mansur, M.A. and Asaduzzaman, M. (2013). Quality and safety aspect of three sun-dried marine fish species: Chinese Pomfret (Stromateus chinensis), Bombay Duck (Harpodon neheriubhuiys) and Ribbon Fish (Trichiurus haumela). World J. Zool., 8(4): 381-387.

Radhika, R. (2018). A seasonal study on proximate composition of major food fishes of Cochin Back water, (CBW) of Kerala, India. Int. J. Adv. Sci. Res. Manag., 3 (8): 229236.

Rahman, M.S.; Rasul, M.G.; Hossain, M.M.; Uddin, W.; Majumdar, B.C.; Sarkar, M.S.I. and Bapary M.A.J. (2017). Impact of spice treatments on the quality and shelf life of sun dried Taki (Channa punctatus). J. Chem. Biol. Physical Sci., 7(2): 409-420.

Rana, M.M.; Chakraborty, S.C. and Saeid, A. (2019). Comparative studies of nutritional, microbial and organoleptic properties of different indigenous dried fish from local market in Bangladesh. Adv. J. Chem., 3(3): 318-327.

Rasul, M.G.; Jahan, I.; Yuan, C.; Sharkar, M.S.I.; Bapary, M.A.J.; Baten, M.A. and Shah, A.K.M.A. (2021). Seasonal variation of nutritional constituents of some freshwater and marine fishes of South Asian Countries: A critical review. Fundamental Applied Agril., 6(2): 51-68.

Rasul, M.G.; Majumdar, B.C.; Afrin, F.; Jahan, M.; Yuan, C. and Shah, A.K.M.A. (2019). Physico-chemical, microbiological and sensory changes in sun-dried Trichogaster fasciata during storage. Turkish JAF Sci. Tech., 7(10): 1568-1574. https://doi.org/10.24925/turjaf.v7i10.1568-1574.2589

Rasul, M.G.; Majumdar, B.C.; Afrin, F.; Bapary, M.A.J. and Shah, A.K.M.A. (2018). Biochemical, microbiological, and sensory properties of dried Silver carp (Hypophthalmichthys molitrix) influenced by various drying methods. Fishes, 3(3), 25. 
Rasul, M.G.; Yuan, C. and Shah, A.K.M.A. (2020). Chemical and microbiological hazards of dried fishes in Bangladesh: A food safety concern. Food Nutr. Sci., 11(6): 523-539.

Rasul, M.G.; Kabir, I. E.; Yuan, C. and Shah, A.K.M.A. (2021a). Effects of drying methods on physico-chemical, microbiological, and sensory properties of Megalaspis cordyla. J. Microbiol. Biotechnol. Food Sci., 11(4): 170-178.

Roos, N.; Wahab, A.M., Chamnan, C. and Thilsted, S.H. (2007). The role of fish in food-based strategies to combat vitamin A and mineral deficiencies in developing countries. .J. Nutr., 137:1106-1109.

Rudkowska, I.; Marcotte, B.; Pilon, G.; Lavigne, C.; Marette, A. and Vohl, M. C. (2010). Fish nutrients decrease expression levels of tumor necrosis factor-alpha in cultured human macrophages. Physiol. Genomics, 40: 189-194.

Salaudeen, M.M. (2014). Quality analysis of dried cod (Gadus morhua) heads along the value chain from Iceland to Nigeria. United Nations University Fisheries Training Programme, Iceland [final project]. http://www.unuftp.is/static/fellows/document/ mutiat13prf.pdf

Simopoulos, A.P. (1999). Essential fatty acids in health and chronic disease. Am. J. Clin. Nutr., 70: 560-569.

Sankar, T.V.; Mathew, S.; Anandan, R.; Asha, K.K. and Mohanty, B.P. (2010). Central Institute of Fisheries Technology handbook on Nutrient Profiling of Fish, p. 5051.

Shah, A.K.M.A.; Tokunaga, C.; Kurihara, H. and Takahashi, K. (2009). Changes in lipids and their contribution to the taste of migaki-nishin (dried herring fillet) during drying. Food Chem., 115(3): 1011-18. https://doi.org/10.1016/j.foodchem.2009.01.02

Siddiky, M.N. I.; Bosu, A.; Roy, B.C.; Sarker, S.K. and Moniruzzaman, M. (2017). Proximate composition analysis of five important dried sea fish and evaluate their nutritive value. Int. J. Natural and Social Sciences, 4(1): 103-110.

Siddique, M.A.M. and Aktar, M. (2011). Changes of nutritional value of three marine dry fishes (Johnius dussumieri, Harpodon nehereus and Lepturacanthus savala) during storage. Food Nutr. Sci., 2(10): 1082-1087.

Swanson, D.; Block, R. and Mousa, S.A. (2012). Omega-3 fatty acids EPA and DHA: health benefits throughout life. Adv. Nutr., 3(1): 1-7.

Sinn, N. (2007). Physical fatty acid deficiency signs in children with ADHD symptoms. Prostaglandins Leukot. Essent. Fatty Acids., 77(2): 109-115.

Stansby, M.E. (1962). Proximate composition of fish. In: Fish in Nutrition, P. 5.5. Ed. by E. Heen and R. Kreuzer. Fishing News (Books) Ltd., Ludgate House, London, E. C. England.

Sultana, S.; Parween, S. and Hossain, M.A. (2011). Biochemical analysis of some dried SIS fishes of the River Padma in Rajshahi. J. Life Earth Sci., 6: 39-43. 
Sutharshiny, S., Sivashanthini, K. (2011). Proximate composition of three species of Scomberoides fish from Sri Lankan waters. Asian J. Clinic. Nutr, 3:103-111. https://doi.org/10.3923/ajen.2011.103.111

Tacon, A.G.J. and Metian, M. (2013). Fish matters: Importance of aquatic foods in human nutrition and global food supply. Rev Fisher Sci., 21:22-38.

Talabi, O. (1995). The influence of traditional handling methods on the quality of processed fish in Nigeria. Proceeding of the conference on the handling, processing and marketing of tropical fish. Tropical product institute, London.

Tilamia, S.K. and Sampels, S. (2017). Nutritional value of Fish: Lipids, proteins, vitamins, and minerals. Rev. Fish. Sci. Aquac., doi: 10.1080/23308249.2017.1399104

Thilsted, S.H.; James, D.; Toppe, J.; Subasinghe, R. and Karunasagar, I. (2014). ICN2 Second International Conference on Nutrition. FAO and World Health Organisation.

Tir, M.; Bejaoui, S. and Chetoui, I. (2017). Effect of different drying procedures on the nutritional value of the mantle and tentacles of Sepia officinalis. J. Am. Oil Chem. Soc., 94(10): 1313-1322. doi:10.1007/s11746-017-3028-5

Ullah, N.; Hazarika, P. and Handique, P.J. (2016). Biochemical quality assessment of ten selected dried fish species of North East India. Int. Adv. Res. J. Sci. Eng. Technol., 3(1): 30-33.

Uhe, A.M.; Collier, G. R. and Dea, K.O (1992). A comparison of the effects of beef, chicken and fish protein on satiety and amino acid profiles in lean male subjects. J. Nutr. 122(3): 467-472.

Weitz, D.; Weintraub, H.; Fisher, E. and Schwartzbard, A.Z. (2010). Fish oil for the treatment of cardiovascular disease. Cardiol Rev., 18(5): 258-263. https://doi.org/ 10.1097/ CRD.0b013e3181ea0de0

Wu, T. and Mao, L. (2008). Influences of hot air drying and microwave drying on nutritional and odorous properties of Grass Carp (Ctenopharyngodon Idellus) fillets. Food. Chem., 110: 647-653. doi: 10.1016/j.foodchem.2008.02.058.

Yilmaz, A.B.; Sangun, M.K.; Yanghoglu, D. and Turan, C. (2010). Metals (major, essential to non-essential) composition of the different tissue of 3 demersal fish species from Iskenderun Bay, Turkey. J. Food Chem., 123 (2): 410-415. 